\title{
USE OF GALACTOMANNAN FROM Caesalpinia pulcherrima IN RESTRUCTURED FISH PRODUCTS STORED UNDER FROZEN CONDITIONS ${ }^{1}$
}

\author{
SANYELLE LIMA SOUSA ${ }^{2 *}$, ÍDILA MARIA DA SILVA ARAÚJO ${ }^{3}$, STELLA REGINA ARCANJO MEDEIROS ${ }^{4}$, \\ ELISABETH MARY CUNHA DA SILVA ${ }^{2}$
}

\begin{abstract}
The objective of this work was to evaluate the use of galactomannan from Caesalpinia pulcherrima as a binding agent for the restructuring of fishes. The effect of a frozen $\left(-18{ }^{\circ} \mathrm{C}\right)$ storage of 120 days on the physical-chemical and mechanical properties of fishes was evaluated, restructured fish products with transglutaminase were used as a control. Two fish restructuring formulations were developed: Galactomannan, with $0.2 \%$ galactomannan and $1.8 \%$ refined salt; and Control, with $0.5 \%$ transglutaminase. The analyses were carried out after 24 hours of refrigerated storage $\left(4{ }^{\circ} \mathrm{C}\right)$, corresponding to time zero, and after $30,60,90$, and 120 days of frozen $\left(-18^{\circ} \mathrm{C}\right)$ storage. The use of galactomannan resulted in a higher $\mathrm{pH}$, and lower total volatile basic nitrogen (TVB-N) and thiobarbituric acid reactive substances (TBARS), with no differences from zero to 120-day storage times for the $\mathrm{L}^{*}, \mathrm{a}^{*}$, and $\mathrm{b}^{*}$ coordinates. Galactomannan easily bounds to hydrogen, enabling the obtaining restructured fish products with lower expressible water content and less weight losses by cooking, important characteristics for the acceptance of products that denote softness and succulence. Contrastingly, this easy bound to water molecules resulted in a lower hardness, cohesiveness, and elasticity, and higher adhesivity when compared to the control. The results showed the viability of using galactomannan to restructure fishes during frozen storage.
\end{abstract}

Keywords: Restructured fish products. Gum. Oligoplites palometa.

\section{O USO DE GALACTOMANANA (Caesalpinia pulcherrima) EM REESTRUTURADO DE PEIXE ESTOCADO SOB CONGELAMENTO}

\begin{abstract}
RESUMO - Este trabalho tem como objetivo avaliar a utilização da galactomanana de Caesalpinia pulcherrima como agente ligante na reestruturação de pescado, examinando as propriedades físico-químicas e mecânicas para determinar o efeito do armazenamento congelamento $-18{ }^{\circ} \mathrm{C}$ durante 120 dias, utilizando como controle o reestruturado de pescado feito com transglutaminase. Foram desenvolvidas duas formulações de reestruturados sendo a Gal com $0.2 \%$ de galactomanana e $1.8 \%$ de sal refinado e o Controle com $0.5 \%$ de transglutaminase. As análises foram realizadas após 24 horas de armazenamento refrigerado $\left(4{ }^{\circ} \mathrm{C}\right)$ correspondente ao tempo zero e depois aos 30, 60, 90 e 120 dias de armazenamento congelado a $-18{ }^{\circ} \mathrm{C}$. Foi observado ao longo do período estudado que a incorporação de galactomanana registrou um aumento no $\mathrm{pH}$, menores valores para as bases voláteis totais (N-BVT) e substâncias reativas ao ácido tiobarbitúrico (TBARS), além de não manifestarem mudanças significativas, entre os tempos zero e 120 dias, nas coordenadas $\mathrm{L}^{*}$, a* e $\mathrm{b}^{*}$. A facilidade da galactomanana em realizar ligações hidrogênio permitiram obter reestruturados com menor teor de água expressível e reduzida perda de peso por cocção, sendo estas características importantes para aceitação dos produtos por proporcionarem maciez e suculência. Por outro lado, está maior facilidade de ligação com a água contribuiu para os menores valores de dureza e coesividade, além de baixa elasticidade e maior adesividade em relação ao controle. Os resultados foram importantes e demonstraram a viabilidade da galactomanana na reestruturação de pescado durante o armazenamento congelado.
\end{abstract}

Palavras-chave: Reestruturado de peixe. Goma. Oligoplites palometa.

\footnotetext{
${ }^{*}$ Corresponding author

${ }^{1}$ Received for publication in $07 / 27 / 2020$; accepted in $03 / 22 / 2021$.

Paper extracted from the doctoral thesis of the first author.

${ }^{2}$ Department of Food Engineering, Universidade Federal do Ceará, Fortaleza, CE, Brazil; sanyellelima@yahoo.com.br - ORCID: 00000002-6214-2026, elisabeth.cunha@gmail.com - ORCID: 0000-0002-3267-4267.

${ }^{3}$ Embrapa Agroindústria Tropical, Fortaleza, CE, Brazil; idila.araujo@embrapa.br - ORCID: 0000-0001-5258-5248.

${ }^{4}$ Department of Nutrition, Universidade Federal do Piauí, Picos, PI, Brazil; stellaarcanjo@yahoo.com.br - ORCID: 0000-0002-0764-9406.
} 


\section{INTRODUCTION}

Caesalpinia pulcherrima, known in Brazil as maravilha, flamboyanzinho, or flor-do-paraíso, is an ornamental plant of the family Leguminosae that presents dehiscent and polyspermic fruits with, on average, seven oblong-oval shape seeds (ARAÚJO NETO et al., 2014). The endosperm of these seeds contain galactomannan, which is a reserve polysaccharide and, chemically, a linear chain of mannose united by glycosides $\beta$ (1-4) bindings, which are associated to residues of galactose by type $\alpha$ (1-6) clusters as substitutes in the carbon 6 of D-mannose (CERQUEIRA et al., 2011).

Galactomannan is extracted from Caesalpinia pulcherrima seeds because it has the capacity to modify viscosity properties and is a thickener, which are similar characteristics to those of commercial gums (THOMBRE; GIDE, 2013). Considering the intense exploration and economic valuation of commercial gums, studies on alternatives sources are important and can enable the use local raw materials, which has the benefits of availability and low cost; one of these alternative sources is the galactomannan. Galactomannan have been studies for its applicability to several foods; however, researches with fish are scarce. Maia et al. (2015) developed nuggets and fish-burgers of tilapia surimi using it as a thickener and evaluated the chemical composition of the products; they found that the addition of this polysaccharide did not affect the products, which presented good acceptance by consumers and high grades in the sensorial analysis done by untrained tasters.

Thus, additional studies are needed to evaluate the effect of galactomannan on fish products, assess its potential as a binding agent in restructuring process of animal products, and evaluate its dynamics during frozen storage. Freezing is the commonly used conservation method for restructured fish products in the retail sector. It is characterized by decreasing the food temperature below its freezing point, when the water state changes to solid forming ice crystals, since the lower the temperature, the lower the speed of microbiological, chemical, and enzymatic changes (TRUONGHUYNH et al., 2020).

The development of restructured fish products prioritizes the obtaining of accessible, nutritionally rich products. In this context, Oligoplites palometa, a fish species known in Brazil as tibiro, is a low-cost fish that presents high nutritional quality and low caloric value (COSTA et al., 2015). This is an underused species that is marketed in urban centers mainly as steaks, but has potential to be used for the development of restructured products, thus improving its used and marketing.

The objective of this study was to evaluate the effect of frozen storage $\left(-18{ }^{\circ} \mathrm{C}\right)$ for 120 days on physical-chemical and mechanical properties of restructured fish (Oligoplites palometa) products prepared with galactomannan from Caesalpinia pulcherrima, using a commercial binding agent with transglutaminase as a control to compare the binder action of galactomannan.

\section{MATERIAIS AND METHODS}

Fish (Oligoplites palometa) steaks and refined salt obtained in markets of Fortaleza, Ceará, Brazil were used. The galactomannan (Caesalpinia pulcherrima) was acquired from the Department of Pharmacy of the University of Fortaleza (UNIFOR). The microbial transglutaminase (ACTIVA GS) used had an enzymatic activity of 47 to $82 \mathrm{Ug}^{-1}$ and contained sodium chloride, gelatin, trisodium phosphate, maltodextrin, transglutaminase, and safflower oil from the Ajinomoto company (São Paulo, Brazil).

The concentrations used for the restructured fish products (Table 1) were defined based on the studies of Maia et al. (2015) for galactomannan, and Monteiro et al. (2015) for transglutaminase (Control).

Table 1. Formulations (g $100 \mathrm{~g}^{-1}$ ) of restructured fish (Oligoplites palometa) products (RFP) using transglutaminase and galactomannan.

\begin{tabular}{ccccc}
\hline RFP & Fish & Transglutaminase & Galactomannan & Refined salt \\
\hline Transglutaminase & 99.5 & 0.5 & 0.0 & 0.0 \\
Galactomannan & 98.0 & 0.0 & 0.2 & 1.8 \\
\hline
\end{tabular}

The fish steaks were crushed in a meat grinder (Skymsen, PS-22) with a disc of $7 \mathrm{~mm}$ diameter. The restructured fish product with galactomannan was prepared using an aqueous dispersion at $80{ }^{\circ} \mathrm{C}$ with a concentration of $1.84 \%$ $\left(\mathrm{w} \mathrm{v}^{-1}\right)$ of galactomannan (Caesalpinia pulcherrima) homogenized for 60 seconds and left to cool under room temperature. The products were prepared in a cutter (Walita, Ri3142); refined salt at concentration of $1.8 \%$ and the galactomannan gel was added to the ground fish at the ratio of 10:90 $\left(\mathrm{w} \mathrm{w}^{-1}\right)$ to obtain a concentration of $0.2 \%$. An additional 120 seconds was required to homogenize the ingredients; the temperature of the mixture did not exceed $10{ }^{\circ} \mathrm{C}$. The Control restructured fish product was prepared following the manufacturer recommendations; it was 
applied as a solution, with a water to ground fish ratio of 1:4.

The restructured fish products were molded in circular shape in aluminum rings with $7 \mathrm{~cm}$ diameter and $16 \mathrm{~mm}$ height, covered with PVC film, placed in identified polyethylene packages, and maintained under refrigeration at $4{ }^{\circ} \mathrm{C}$ for 24 hours for cold restructuring, as described by Moreno, Carballo and Borderías (2008). The analyses at time zero were done after 24 hours; the remaining products were subjected to slow freezing up to $-18{ }^{\circ} \mathrm{C}$ and then thawed in a refrigerator at $10^{\circ} \mathrm{C}$ after $30,60,90$ and 120 days of frozen storage for evaluation.

The $\mathrm{pH}$ was determined in a 5-gram samples by adding $50 \mathrm{~mL}$ of distilled water and subject them to direct readings using a surface pHmeter (Tecnal, R-TEC7MP), with three replications.

Total volatile basic nitrogen (TVB-N) was evaluated in $30 \mathrm{~g}$ samples macerated for one minute in a mortar with $30 \mathrm{~mL}$ of $10 \%$ trichloroacetic acid (TCA). The mixture was left to rest for 30 minutes and then sieved and passed through a paper filter.

Microdiffusion dishes (Conway) were prepared with $2 \mathrm{~mL}$ of boric acid $(1 \%)$ and Tashiro indicator in the central compartment, and $2 \mathrm{~mL}$ of the sample extract, $1 \mathrm{~mL}$ of formol (35\%), and $2 \mathrm{~mL}$ of a saturated potassium carbonate solution in the external compartment. Lids with silicone grease were immediately placed on the dishes and fixed with metal clips, and a slight homogenization was needed to mix the contents of the external compartment; the dishes were maintained at $35-36^{\circ}$ $\mathrm{C}$ in an oven for two hours. Then, the mixtures were titrated in a hydrochloric acid solution $(0.01 \mathrm{M})$. The analyses were done with three replications; the contents were expressed as mg of TVB-N $100 \mathrm{~g}^{-1}$, following the Conway microdiffusion methodology (CONWAY; BYRNE, 1993), using Equation 1:

$$
T V B-N=\frac{(V x N \times 1400) x(T \times V)}{(V A x P)}
$$

where $V$ is the volume $(\mathrm{mL})$ of $\mathrm{HCl} 0.01 \mathrm{~N}$ used for the titration; $N$ is the normality of the $\mathrm{HCl}$ $0.01 \mathrm{~N}$ solution; $T$ is the volume $(\mathrm{mL})$ of the $10 \%$ TCA solution used; $U$ is the sample moisture; $V A$ is the volume $(\mathrm{mL})$ of the aliquot of the extract; and $P$ is the weight of the sample used for the preparation of the extract.

Thiobarbituric acid reactive substances (TBARS) were determined using the methodology described by Raharjo, Sofos and Schmidt (1992), with changes; $1 \mathrm{~mL}$ of BHT $(0.15 \%)$ and $40 \mathrm{~mL}$ of $5 \%$ TCA was added to $10 \mathrm{~g}$ sample of the extract and the mixture was centrifuged at $4{ }^{\circ} \mathrm{C}$ and $10.000 \mathrm{rpm}$ for ten minutes. The resulting supernatant was filtered and transferred to a $50 \mathrm{~mL}$ volumetric flask, whose volume was completed with 5\% TCA. An aliquot of $2 \mathrm{~mL}$ of this solution was transferred to a test tube and $2 \mathrm{~mL}$ of TBA $(0.08 \mathrm{M})$ in $50 \%$ acetic acid solution was added; the mixture was subjected to a water bath at $94 \pm 1{ }^{\circ} \mathrm{C}$ for 50 minutes. After cooling in an ice bath, absorbance readings were carried out in a spectrophotometer using the wavelength of $531 \mathrm{~nm}$. This procedure was done with three replications; the TBARS were calculated and expressed as $\mathrm{mg}$ of malonaldehyde per $\mathrm{kg}$ of sample, according to Equation 2:

$$
T B A R S=\frac{(25 \times C)}{P}
$$

where $P$ is the weight of the sample $(\mathrm{g}) ; 25$ is the dilution factor; and $C$ is the concentration corresponding to the absorbance in the standard curve ( $\mu \mathrm{g}$ of malonaldehyde $2 \mathrm{~mL}^{-1}$ ).

The color analysis was carried out using a spectrocolorimeter (HunterLab, Colorquest XE); samples were arranged in $10 \mathrm{~mm}$-thick glass cuvettes and read by excluded specular reflection (without light) in an area of $5.07 \mathrm{~cm}^{2}$ of the sample. The measurements were carried out with four replicates and the results of the readings were obtained through the EasyMatch QC 4.81 program linked to the device, following the CIE colorimetric system $\left(L^{*} a^{*} b^{*}\right)$.

The analysis of expressible water $\left(\mathrm{W}_{\mathrm{E}}\right)$ was used as an indirectly and inversely proportional measure to the water retention capacity. Samples of $2 \pm 0.2 \mathrm{~g}$ were placed in two layers of filter paper, arranged in $50 \mathrm{~mL}$ centrifuge tubes, and subjected to centrifugation at $1000 \mathrm{~g}$ for $15 \mathrm{~min}$ at $4{ }^{\circ} \mathrm{C}$. The wet filter papers were then removed and the samples were weighed again; five of them were analyzed for each treatment (MARTELO-VIDAL; MESAS; VÁZQUEZ, 2012). The percentage of expressible water was calculated according to Equation 3:

$$
W_{E}(\%)=\frac{\left(P_{0^{-}} P\right)}{P_{0}} \times 100
$$

where $W_{E}$ is the percentage of expressible water; $P_{0}$ is the initial weight; and $P$ is the final weight.

The weight loss by cooking was analyzed following the methodology proposed by Liu et al. (2004), with four replications. The samples were cut in rectangular formats, placed in polyethylene plastic bags, and cooked in a water bath at $85{ }^{\circ} \mathrm{C}$ for 25 minutes. The samples were then withdrawn from the packaging, cooled in flowing water, and the surface was carefully dried with an absorbent paper. The difference between the initial and final weights 
corresponded to the weight loss by cooking (WLC), calculated according to Equation 4:

$$
W L C(\%)=\frac{\left(\text { Weight }_{\text {before cooking }}-\text { Weight }_{\text {after cooking }}\right)}{\text { Weight }_{\text {before cooking }}} \times 100
$$

The texture profile analyses were carried out using a texturometer (Stable Micro System, TA-XT2i) with a $5 \mathrm{~kg}$ load cell, following the methodology described by Kunnath et al. (2015), using a $50 \mathrm{~mm}$-diameter cylindrical probe. Ten tests were carried out for each treatment; the samples were axially compressed up to $75 \%$ of their original height, with pre-test speed of $2 \mathrm{~mm} \mathrm{~s}^{-1}$, test speed of $1 \mathrm{~mm} \mathrm{~s}^{-1}$, and post-test speed of $5 \mathrm{~mm} \mathrm{~s}^{-1}$. The probe penetration distance was $30 \mathrm{~mm}$ and the time between the first and second compressions was $2.5 \mathrm{~s}$. The samples were placed in the base-board and compressed and decompressed twice by the cylindrical probe, thus generating a graphic curve. The attributes measured were hardness (peak force needed for the first compression; g); cohesiveness (active work in the first compression curve; dimensionless); elasticity (recovering distance of the sample after the first compression); and adhesivity (area of negative force in the first compression).

The data were expressed as means and standard deviations. The results were subjected to analysis of variance (ANOVA) by the F test and the means were compared by the Tukey's test at $5 \%$.
The data of transformations during the frozen storage over time were evaluated through polynomial regression, using second-degree equations. The minimum coefficient of determination for the use of the curves was $70 \%$. The analyses were carried out using computational resources of the Statistica 7.0 program (STATSOFT, 2008).

\section{RESULTS AND DISCUSSIONS}

The $\mathrm{pH}$ means in the restructured fish products of Oligoplites palometa (RFP) over the 120 days of storage are shown in Table 2 . The $\mathrm{pH}$ values indicated the acidity, alkalinity, or neutrality of the fish muscle in an aqueous medium, and, although not conclusive to evaluate the freshness degree, it is still applied as a parameter for quality evaluation (SOARES; GONÇALVES, 2012). The $\mathrm{pH}$ data of the Control fitted to second-degree polynomial equation, presenting a coefficient of determination $\left(\mathrm{R}^{2}\right)$ of 0.78 ; whereas the data found for the Galactomannan RFP did not fit to the regression equation, presenting a coefficient of determination $\left(\mathrm{R}^{2}\right)$ lower than 0.70 . The $\mathrm{pH}$ of the Galactomannan and Control RFP at the beginning (day zero) and end (120 days) of storage were similar. Control RFP showed higher $\mathrm{pH}$ after 30 and 90 days, and Galactomannan RFP showed higher $\mathrm{pH}$ after 60 days of storage.

Table 2. Values of $\mathrm{pH}$ of restructured fish (Oligoplites palometa) products (RFP) developed with transglutaminase (Control) and Galactomannan, stored under frozen conditions for 120 days.

\begin{tabular}{ccc}
\hline \multirow{2}{*}{ Storage time (Days) } & \multicolumn{2}{c}{$\mathrm{pH}$} \\
\cline { 2 - 3 } & Control RFP & Galactomannan RFP \\
\hline 0 & $6.27^{\mathrm{aC}} \pm 0.00$ & $6.29^{\mathrm{aC}} \pm 0.00$ \\
30 & $6.40^{\mathrm{aAB}} \pm 0.00$ & $6.34^{\mathrm{bB}} \pm 0.00$ \\
60 & $6.37^{\mathrm{bB}} \pm 0.01$ & $6.41^{\mathrm{aA}} \pm 0.00$ \\
90 & $6.42^{\mathrm{aA}} \pm 0.00$ & $6.33^{\mathrm{bB}} \pm 0.00$ \\
120 & $6.39^{\mathrm{aAB}} \pm 0.02$ & $6.40^{\mathrm{aA}} \pm 0.01$ \\
\hline
\end{tabular}

Means followed by the same lowercase letter in the rows comparing RFP, or uppercase letter in the columns comparing storage times, are not different $(\mathrm{p} \geq 0.05)$.

The limits established by the Brazilian legislation considers $\mathrm{pH}$ lower than 7.0 as a reference for fresh fishes (BRASIL, 2017). Despite the increases in $\mathrm{pH}$ at some storage times in both RFP, they remained lower than the legal standards. These increases are expected, since the use of hydrocolloids such as galactomannan can change the conformation of proteins, exposing basic groups that may increase the $\mathrm{pH}$, and transglutaminase catalyzes reactions that release ammonia (ANDRÉS-BELLO et al., 2013; YERLIKAYA et al., 2017). In addition, reactions that change quality parameters are not all interrupted, even when stored under frozen conditions $\left(-18{ }^{\circ} \mathrm{C}\right)$. Therefore, $\mathrm{pH}$ increases in muscles indicate increases in alkaline compounds that may be from microbial action and other endogenous proteolytic activity, including trimethylamine and ammonia (SOTO-VALDEZ et al., 2015).

The mean total volatile basic nitrogen (TVBN) and thiobarbituric acid reactive substances (TBARS) of the RFP over the storage time are 
shown in Table 3. The TVB-N means over the storage time of the two RFP were significantly different, with increases over time. The TVB-N means of the Control and Galactomannan RFP at the end of the storage period had not exceeded the limit established recommended by the Brazilian Ministry of Agriculture, Livestock, and Supply (MAPA) of

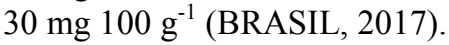

Table 3. Total volatile basic nitrogen (TVB-N) and thiobarbituric acid reactive substances (TBARS) of restructured fish (Oligoplites palometa) products (RFP) developed with transglutaminase (Control) and Galactomannan, stored under frozen conditions for 120 days.

\begin{tabular}{clllc}
\hline \multirow{2}{*}{$\begin{array}{c}\text { Storage time } \\
\text { (Days) }\end{array}$} & \multicolumn{2}{c}{ TVB-N $\left(\mathrm{mg} 100 \mathrm{~g}^{-1}\right)$} & \multicolumn{3}{c}{ TBARS (mg of malonaldehyde $\left.\mathrm{Kg}^{-1}\right)$} \\
\cline { 2 - 5 } & Control RFP & Galactomannan RFP & Control RFP & Galactomannan RFP \\
\hline 0 & $1.83^{\mathrm{aE}} \pm 0.16$ & $1.37^{\mathrm{bE}} \pm 0.00$ & $0.80^{\mathrm{bC}} \pm 0.00$ & $0.90^{\mathrm{aA}} \pm 0.00$ \\
30 & $2.83^{\mathrm{aD}} \pm 0.07$ & $2.47^{\mathrm{bD}} \pm 0.00$ & $0.98^{\mathrm{aB}} \pm 0.01$ & $0.88^{\mathrm{bB}} \pm 0.00$ \\
60 & $3.41^{\mathrm{aC}} \pm 0.08$ & $2.85^{\mathrm{bC}} \pm 0.08$ & $0.97^{\mathrm{aB}} \pm 0.00$ & $0.74^{\mathrm{bD}} \pm 0.00$ \\
90 & $3.81^{\mathrm{aB}} \pm 0.07$ & $3.22^{\mathrm{bB}} \pm 0.08$ & $0.98^{\mathrm{aB}} \pm 0.02$ & $0.82^{\mathrm{bC}} \pm 0.00$ \\
120 & $4.64^{\mathrm{aA}} \pm 0.07$ & $3.82^{\mathrm{bA}} \pm 0.08$ & $1.14^{\mathrm{aA}} \pm 0.01$ & $0.89^{\mathrm{bAB}} \pm 0.00$ \\
\hline
\end{tabular}

Means followed by the same lowercase letter in the rows comparing RFP, or uppercase letter in the columns comparing storage times, are not different $(\mathrm{p} \geq 0.05)$.

The TVB-N of the Control RFP were higher than that of the Galactomannan RFP in all storage times. This is explained by the catalyzes of the transglutaminase, which form cross links within and between molecules of different proteins, releasing ammonia in this process (YERLIKAYA et al., 2017), which contributes to increase TVB-N contents. The TVB-N means of both RFP fitted to linear equations with high coefficients of determination, presenting $\mathrm{R}^{2}$ of 0.98 (Control RFP) and 0.95 (Galactomannan RFP); thus, the data can be used to estimate TVB-N values.

The TBARS found in the RFP (Table 3) showed that the Control RFP had a stable TBARS content from 30 to 90 days, with increases by the end of storage. These data fitted to a linear equation with a coefficient of determination $\left(\mathrm{R}^{2}\right)$ of 0.81 , denoting a positive correlation with the storage time. The TBARS were higher in the Control RFP than in the Galactomannan RFP, except at time zero. Moreno, Borderías and Baron (2010) evaluated chopped trout (O. mykiss) and hake (M. merluccius) muscles stored under refrigerated conditions $\left(4^{\circ} \mathrm{C}\right)$ for 6 days and found similar results; they attributed these results to a possible pro-oxidizer effect by bounds promoted by transglutaminase enzymes that trigger oxidative reactions. In addition, Moreno, Carballo and Borderías (2010) presented the hypothesis of a possible interference of transglutaminase in TBARS analyses, which could overestimate the results.

The TBARS means of Galactomannan RFP did not increase over the storage time, with no significant difference from the day zero to 120 days of storage at $-18{ }^{\circ} \mathrm{C}$. The malonaldehyde contents decreased from 60 to 90 days; malonaldehyde contents vary due to the different stages of decomposition of peroxide and interactions of some substances in the muscle structure at the time of analysis. Therefore, the TBARS data showed a best fit to the second-degree polynomial equation, with coefficient of determination $\left(R^{2}\right)$ of 0.70 . Galactomannan probably had no effect on oxidative reactions over the storage time; however, there is no study explaining its effect on lipid oxidation of ground fish. Similar substances to galactomannan, such as guar and xanthan gums, are reported in the literature as iron chelator agents that inactivate peroxyl radicals, inhibiting lipid oxidation. This was pointed out by Rather et al. (2016) when studying meat emulsions with low fat contents, in which they obtained lower TBARS. In addition, Khouryieh et al. (2015) attributed the high viscosity of locust bean and xanthan gums as an obstacle for diffusion of oxidizers, which delays lipid oxidation rate in oil emulsions in water stabilized with milk protein serum.

The Brazilian legislation does not indicate a limit for lipid oxidation measured by TBARS for fish products, since this value vary according to the product; however, according to Cartonilho and Jesus (2011), TBARS contents below $3.0 \mathrm{mg}$ of malonaldehyde $\mathrm{kg}^{-1}$ indicate good conservation status for fishes; thus, the RFP presented acceptable quality at the end of the storage time (120 days).

The highest mean light ( $\left.\mathrm{L}^{*}\right)$ over the storage time in the Control RFP was found at the initial time (58.21) and the lowest at 30 days (55.27) of storage, and was more stable from 60 to 120 days of storage (Table 4). The L* of Galactomannan RFP changed little, with the lowest value at 30 days, and stable values up to the end of storage. The Control RFP had higher $\mathrm{L}^{*}$ values than the Galactomannan RFP up to 
60 days of storage and no significant differences in $\mathrm{L}^{*}$ from 60 days to the end of storage time. The $\mathrm{L}^{*}$ data found for the Control RFP did not fit to the equation, presenting coefficient of determination
$\left(\mathrm{R}^{2}\right)$ lower than 0.70 ; whereas the data of $\mathrm{L}^{*}$ of Galactomannan RFP fitted to the second-degree polynomial equation, with a coefficient of determination $\left(\mathrm{R}^{2}\right)$ of 0.72 .

Table 4. Light coordinate $\left(\mathrm{L}^{*}\right)$ of restructured fish (Oligoplites palometa) products (RFP) developed with transglutaminase (Control) and Galactomannan, stored under frozen conditions for 120 days.

\begin{tabular}{ccc}
\hline Storage time (Days) & Light coordinate $\left(\mathrm{L}^{*}\right)$ \\
\cline { 2 - 3 } & Control RFP & Galactomannan RFP \\
\hline 0 & $58.21^{\mathrm{aA}} \pm 0.26$ & $55.62^{\mathrm{bA}} \pm 0.05$ \\
30 & $55.27^{\mathrm{aC}} \pm 0.27$ & $54.03^{\mathrm{bB}} \pm 0.83$ \\
60 & $56.99^{\mathrm{aAB}} \pm 0.16$ & $54.64^{\mathrm{bAB}} \pm 0.19$ \\
90 & $56.55^{\mathrm{aBC}} \pm 0.43$ & $55.66^{\mathrm{aA}} \pm 0.75$ \\
120 & $55.47^{\mathrm{aBC}} \pm 1.25$ & $56.08^{\mathrm{aA}} \pm 0.40$ \\
\hline
\end{tabular}

Means followed by the same lowercase letter in the rows comparing RFP, or uppercase letter in the columns comparing storage times, are not different $(\mathrm{p} \geq 0.05)$.

The results found for the coordinates $\mathrm{a}^{*}$ and $\mathrm{b}^{*}$ are shown in Table 5 . The results of red color $\left(\mathrm{a}^{*}\right)$ found for the Control and Galactomannan RFP did not fit to the equations, presenting coefficients of determination $\left(\mathrm{R}^{2}\right)$ lower than 0.70 . The $\mathrm{a}^{*}$ values found for the Control RFP were higher due to the reddish color of the solution prepared with transglutaminase; these values decreased after 60 days of storage and stabilized by the end of storage time. According to Sánchez-Alonso et al. (2011), decreases in $a^{*}$ over the storage time are related to increases in oxidative reactions; they found decreases in $a^{*}$ for RFP of horse mackerel under refrigerated storage and attributed it to the oxidation of oxymyoglobin into metmyoglobin. Galactomannan RFP presented no significant difference from time zero to 120 days of storage, with light decreases at 60 days; therefore, $a^{*}$ values were not affected by the storage time.

The highest values of coordinate $b^{*}$ were found for the Control RFP, which exhibited a slight increase by the end of the storage time. The data fitted to the linear regression, presenting a $R^{2}$ of 0.75 , describing the dynamics of $b^{*}$ over the storage time. However, the $b^{*}$ values found for Galactomannan RFP did not fit to the regression equation. The highest $b^{*}$ values were found at 30 and 120 days of storage. Increases in $b^{*}$ values are due to accumulation of byproducts of lipid oxidation that can cause yellowing of the RFP (SÁNCHEZALONSO et al., 2011).

Table 5. Color coordinates ( $\mathrm{a}^{*}$ and $\mathrm{b}^{*}$ ) of restructured fish (Oligoplites palometa) products (RFP) developed with transglutaminase (Control) and Galactomannan, stored under frozen conditions for 120 days.

\begin{tabular}{ccccc}
\hline \multirow{2}{*}{ Storage time (Days) } & \multicolumn{2}{c}{$\mathrm{a}^{*}$ color coordinate } & \multicolumn{2}{c}{$\mathrm{b}^{*}$ color coordinate } \\
\cline { 2 - 5 } & Control RFP & Galactomannan RFP & Control RFP & Galactomannan RFP \\
\hline 0 & $2.39^{\mathrm{aA}} \pm 0.17$ & $1.68^{\mathrm{bAB}} \pm 0.06$ & $14.94^{\mathrm{aC}} \pm 0.04$ & $13.43^{\mathrm{bB}} \pm 0.32$ \\
30 & $2.42^{\mathrm{aA}} \pm 0.07$ & $1.80^{\mathrm{bA}} \pm 0.03$ & $15.59^{\mathrm{aBC}} \pm 0.23$ & $14.11^{\mathrm{bA}} \pm 0.17$ \\
60 & $2.00^{\mathrm{aB}} \pm 0.08$ & $1.20^{\mathrm{bC}} \pm 0.02$ & $15.71^{\mathrm{aB}} \pm 0.07$ & $12.97^{\mathrm{bBC}} \pm 0.00$ \\
90 & $1.89^{\mathrm{aB}} \pm 0.06$ & $1.50^{\mathrm{bB}} \pm 0.23$ & $15.62^{\mathrm{aBC}} \pm 0.05$ & $12.58^{\mathrm{bC}} \pm 0.36$ \\
120 & $1.95^{\mathrm{aB}} \pm 0.02$ & $1.62^{\mathrm{bAB}} \pm 0.03$ & $17.16^{\mathrm{aA}} \pm 0.52$ & $14.29^{\mathrm{bA}} \pm 0.20$ \\
\hline
\end{tabular}

Means followed by the same lowercase letter in the rows comparing RFP, or uppercase letter in the columns comparing storage times, are not different $(\mathrm{p} \geq 0.05)$.

The means of expressible water $\left(\mathrm{W}_{\mathrm{E}}\right)$ and weight loss by cooking (WLC) of the RFP (Table 6) showed that the Control RFP had higher $\mathrm{W}_{\mathrm{E}}$ than the Galactomannan RFP in all storage times analyzed, indicating that Galactomannan RFP have higher water retention capacity, which is positive from the yield point of view. This is explained by the typical dynamic of galactomannan; it is an abundant neutral polysaccharide in hydroxyl groups that facilitate hydrogen bounds, favoring the bindings with water 
(MEDEIROS et al., 2020). The $\mathrm{W}_{\mathrm{E}}$ of Galactomannan RFP varied little over the storage time. $\mathrm{W}_{\mathrm{E}}$ contents were stable, with no significant difference between storage times, except at 30 days, when it was lower. The data did not fit to the regression model; thus, $\mathrm{W}_{\mathrm{E}}$ content in the Galactomannan RFP were not affected by the frozen storage.

Table 6. Expressible water $\left(\mathrm{W}_{\mathrm{E}}\right)$ and weight loss by cooking (WLC) of restructured fish (Oligoplites palometa) products (RFP) developed with transglutaminase (Control) and Galactomannan, stored under frozen conditions for 120 days.

\begin{tabular}{ccccc}
\hline \multirow{2}{*}{ Storage time (Days) } & \multicolumn{2}{c}{$\mathrm{W}_{\mathrm{E}}(\%)$} & \multicolumn{3}{c}{ WLC $(\%)$} \\
\cline { 2 - 5 } & Control RFP & Galactomannan RFP & Control RFP & Galactomannan RFP \\
\hline 0 & $30.01^{\mathrm{aB}} \pm 0.72$ & $17.75^{\mathrm{bA}} \pm 0.82$ & $26.17^{\mathrm{aA}} \pm 0.51$ & $6.44^{\mathrm{bC}} \pm 0.13$ \\
30 & $28.63^{\mathrm{aB}} \pm 0.50$ & $13.23^{\mathrm{bB}} \pm 0.57$ & $19.67^{\mathrm{aB}} \pm 1.40$ & $4.96^{\mathrm{bD}} \pm 0.32$ \\
60 & $30.04^{\mathrm{aB}} \pm 1.18$ & $15.95^{\mathrm{bAB}} \pm 1.51$ & $19.92^{\mathrm{aB}} \pm 0.51$ & $7.74^{\mathrm{bAB}} \pm 0.53$ \\
90 & $34.39^{\mathrm{aA}} \pm 0.37$ & $14.55^{\mathrm{bAB}} \pm 2.85$ & $25.79^{\mathrm{aA}} \pm 0.51$ & $6.94^{\mathrm{bC}} \pm 0.42$ \\
120 & $34.46^{\mathrm{aA}} \pm 0.44$ & $17.59^{\mathrm{bA}} \pm 0.50$ & $25.38^{\mathrm{aA}} \pm 0.51$ & $8.44^{\mathrm{bA}} \pm 0.35$ \\
\hline
\end{tabular}

Means followed by the same lowercase letter in the rows comparing RFP, or uppercase letter in the columns comparing storage times, are not different $(\mathrm{p} \geq 0.05)$.

The $\mathrm{W}_{\mathrm{E}}$ means found for the Control RFP fitted to a linear equation with $\mathrm{R}^{2}$ of 0.72 . The $\mathrm{W}_{\mathrm{E}}$ content were constant up to 60 days of storage, increased at 90 days, and stable by the end of the storage time. Increases in $\mathrm{W}_{\mathrm{E}}$ with consequent decreases in water retention capacity in the Control RFP can be attributed to decreases in reticulation of proteins that release water molecules retained in the protein net (KUNNATH et al., 2015). These increases are also a consequence of the frozen storage, since the ice crystallization disorganize protein net, causing gradual losses in water retention capacity over the storage time (MORENO; CARBALLO; BORDERÍAS, 2010).

The results of weight loss by cooking (WLC) were higher for the Control RFP, confirming the results of $\mathrm{W}_{\mathrm{E}}$. A more exudative appearance was found during the manipulation of these RFP, denoting an excessive weight loss by dripping after the thawing.

The lowest WLC values were found at 30 and 60 days of storage, which were statistically equal; however, the results for the times zero, 90, and 120 days of storage were similar. Galactomannan RFP presented the lowest WLC at 30 days, but with a slight increase over the storage time; however, it was approximately $35 \%$ lower than that in the Control RFP after 120 days of storage. The WLC means of the two RFP did not fit to the regression model $\left(\mathrm{R}^{2}<\right.$ 0.70 ) and, therefore, did not vary as a function of storage time.

The lower WLC of the Galactomannan RFP confirm its better water retention capacity, denoting that the interaction with water was preserved, even after the cooking process, ensuring the product softness and succulence. The slight increase in WLC by the end of the storage time may be related to the formation of ice crystals and the partial dehydration that decrease the water-hydrocolloid stability and interaction. This was found by Solo-de-Zaldívar et al. (2014), who developed RFP of hake (Merluccius capensis) using $1.25 \%$ konjac gum and $0.8 \% \mathrm{NaCl}$ and found WLC varying from $7.7 \%$ to $24.7 \%$ over 150 days of frozen storage.

The means found for hardness and cohesiveness of texture profile of the RFP are shown in Table 7. Hardness means of both RFP did not significantly fit to the regression model or to high precision models. The hardness of the Control RFP, initially, indicated higher values, reaching a peak at 30 days, but tended to decrease, presenting a very lower hardness by the end of the storage time when compared to the initial time. The two RFP presented similar hardness at 60 days of storage, and the Control had lower hardness at 120 days of storage than the Galactomannan RFP.

According to Monteiro et al. (2015), hardness increases over the storage in tilapia steaks (RFP) with different concentrations of transglutaminase, as also found by Kunnath et al. (2015) for RFP of basa (Pangasius sp.) with different combinations of sodium caseinate, egg white, salt, and transglutaminase. However, the results of the present experiment showed a decrease in hardness in the Control RFP, which is explained by the highest exudation of these samples and the decrease in the activity of this enzyme under the frozen condition, which intermediate cross bounds between proteins. In addition, the oxidative modification of proteins by the interaction with products of lipid or protein oxidations or attack of free radicals can decrease the transglutaminase activity (MORENO; BORDERÍAS; BARON, 2010). 
Table 7. Hardness (g) and cohesiveness of restructured fish (Oligoplites palometa) products (RFP) developed with transglutaminase (Control) and Galactomannan and stored under frozen conditions for 120 days.

\begin{tabular}{ccccc}
\hline \multirow{2}{*}{ Storage time (Days) } & \multicolumn{2}{c}{ Hardness $(\mathrm{g})$} & \multicolumn{2}{c}{ Cohesiveness } \\
\cline { 2 - 5 } & Control RFP & Galactomannan RFP & Control RFP & Galactomannan RFP \\
\hline 0 & $2753.01^{\mathrm{aC}} \pm 52.69$ & $2213.51^{\mathrm{bD}} \pm 7.84$ & $0.13^{\mathrm{aC}} \pm 0.00$ & $0.13^{\mathrm{aC}} \pm 0.00$ \\
30 & $7424.35^{\mathrm{aA}} \pm 207.28$ & $2884.10^{\mathrm{bB}} \pm 11.00$ & $0.15^{\mathrm{aC}} \pm 0.00$ & $0.10^{\mathrm{bD}} \pm 0.00$ \\
60 & $3535.99^{\mathrm{aB}} \pm 189.38$ & $3334.21^{\mathrm{aA}} \pm 3.87$ & $0.20^{\mathrm{aB}} \pm 0.00$ & $0.16^{\mathrm{bB}} \pm 0.01$ \\
90 & $2870.19^{\mathrm{aC}} \pm 0.79$ & $2485.22^{\mathrm{bC}} \pm 95.33$ & $0.26^{\mathrm{aA}} \pm 0.01$ & $0.21^{\mathrm{bA}} \pm 0.01$ \\
120 & $1590.71^{\mathrm{bD}} \pm 141.04$ & $2454.48^{\mathrm{aC}} \pm 3.58$ & $0.26^{\mathrm{aA}} \pm 0.02$ & $0.23^{\mathrm{bA}} \pm 0.02$ \\
\hline
\end{tabular}

Means followed by the same lowercase letter in the rows comparing RFP, or uppercase letter in the columns comparing storage times, are not different ( $\mathrm{p} \geq 0.05)$.

The hardness of Galactomannan RFP increased up to 60 days of storage, but decreased and stabilized up to the end of the storage time. AndrésBello et al. (2013) found similar results for RFP of gilthead sea bream (Sparus aurata) developed with konjac gum, transglutaminase, and carboxymethylcellulose, using frozen storage, and attributed these results to the occurrence of molecular changes, including the acting of endogenous transglutaminase and changes in noncovalent bindings between proteins. Galactomannan RFP presented lower hardness than the Control RFP up to 90 days of storage due to the values of $W_{E}$, which correspond to the highest water retention in these RFP, generating a lower resistance to structural disintegration. The higher water contents in the product due to the presence of hydrocolloids results in a slightly inferior textural properties, as reported by Kim et al. (2018). Despite the lower hardness values over most of the storage time, Galactomannan RFP presented no damages and preserved shape during the whole period evaluated. This is important for restructured products that did not pass through any thermal treatment for stabilization.

The means of cohesiveness of Control RFP were higher than those of the Galactomannan RFP in all storage times, except at time zero (Table 7). The cohesion was stable up to 30 days, increased from 60 to 90 days, and presented statistically higher means for Galactomannan RFP at the end of the storage time. The results presented a trend of increasing over the storage time and fitted to a linear regression model with high coefficient of determination $\left(\mathrm{R}^{2}=0.97\right)$, denoting that they can be used to predict cohesiveness dynamics over time. Therefore, despite the decrease in hardness over the storage time in the Control RFP, the internal structure had better resistance to fractures because transglutaminase forms a protein net from intra and intermolecular cross covalent bindings (BONFIM et al., 2015).

Similar to the hardness results, the lowest cohesiveness results were found for the Galactomannan RFP, which presented lower compaction due to the higher water contents in the RFP; in addition, the presence of more internal spaces contributed to decrease the cohesiveness. Probably, the galactomannan was not directly interacting with the proteins, but forming a main net that incorporates muscle components. Therefore, this net had lower internal resistance when compared to that of the Control RFP, in which transglutaminase promote protein-protein bindings, which are more resistant to compression. The cohesiveness of Galactomannan RFP increased from 60 to 90 days and was stable by the end of the storage time. The data of cohesiveness of Galactomannan RFP fitted to a linear regression model with a $\mathrm{R}^{2}$ of 0.78 , indicating a positive correlation with storage time. A hypothesis for the increase in cohesiveness in Galactomannan RFP is the later stabilization of the gel matrix formed, which occurs slower than that for transglutaminase, since both result in different interactions that maintain the muscle restructured.

The means of elasticity and adhesivity found for the RFP are shown in Table 8. The means of elasticity found for the Control and Galactomannan RFP over the storage time did not fit to the regression equation. The elasticity of the Control RFP was higher at 30 days of storage, and stable from 60 to 120 days of storage, with no significant difference. The means of elasticity of Galactomannan RFP varied from 0.13 to 0.24 , with little variation over the storage time. The Control RFP presented higher elasticity means than the Galactomannan RFP in all evaluated times because of its higher cohesion and resistance to compression, which assists in the partially recovering its original form.

The adhesivity means presented no significant differences over the storage time for the Galactomannan RFP; the Control RFP presented the lowest adhesivity at 60 days and the highest at 120 days. The adhesivity results found for the Control and Galactomannan RFP denoted a positive correlation with storage time, and fitted to a seconddegree polynomial equation, with coefficients of 
determination $\left(\mathrm{R}^{2}\right)$ of 0.87 and 0.79 , respectively. Adhesivity presents negative values; the closer to zero, the less sticky the sample, leaving little residue on the cylindrical probe during the test. The means of adhesivity of the Control RFP were statistically higher than those found for the Galactomannan RFP in all the times evaluated, indicating that the use of the transglutaminase enzyme result in less sticky products, which is positive during the manipulation of product. These results confirm the cohesiveness found, since more cohesive products tend to be less adherent and elastic.

Table 8. Elasticity and adhesivity of restructured fish (Oligoplites palometa) products (RFP) developed with transglutaminase (Control) and Galactomannan, stored under frozen conditions for 120 days.

\begin{tabular}{ccccc}
\hline \multirow{2}{*}{ Storage time (Days) } & \multicolumn{2}{c}{ Elasticity } & \multicolumn{2}{c}{ Adhesiveness } \\
\cline { 2 - 5 } & Control RFP & Galactomannan RFP & Control RFP & Galactomannan RFP \\
\hline 0 & $0.52^{\mathrm{aC}} \pm 0.02$ & $0.21^{\mathrm{bAB}} \pm 0.02$ & $-369.82^{\mathrm{aBC}} \pm 5.36$ & $-1913.95^{\mathrm{bA}} \pm 11.07$ \\
30 & $0.99^{\mathrm{aA}} \pm 0.00$ & $0.13^{\mathrm{bB}} \pm 0.00$ & $-373.13^{\mathrm{aBC}} \pm 22.66$ & $-1923.63^{\mathrm{bA}} \pm 19.49$ \\
60 & $0.80^{\mathrm{aB}} \pm 0.00$ & $0.20^{\mathrm{bAB}} \pm 0.01$ & $-434.91^{\mathrm{aC}} \pm 38.05$ & $-1945.36^{\mathrm{bA}} \pm 130.94$ \\
90 & $0.76^{\mathrm{aB}} \pm 0.01$ & $0.19^{\mathrm{bAB}} \pm 0.07$ & $-354.09^{\mathrm{aB}} \pm 37.84$ & $-1908.95^{\mathrm{bA}} \pm 63.16$ \\
120 & $0.77^{\mathrm{aB}} \pm 0.00$ & $0.24^{\mathrm{bA}} \pm 0.03$ & $-259.93^{\mathrm{aA}} \pm 26.12$ & $-1892.63^{\mathrm{bA}} \pm 134.47$ \\
\hline
\end{tabular}

Means followed by the same lowercase letter in the rows comparing RFP, or uppercase letter in the columns comparing storage times, are not different $(\mathrm{p} \geq 0.05)$

These results are due to the bindings between the materials used; the Control RFP presented a higher number of protein-protein bindings, and Galactomannan RFP presented predominance of the galactomannan hydrocolloid, a substance with high viscosity, with a more diluted protein structure, thus increasing the viscosity. According to Mendes et al. (2017), the viscosity of galactomannan from $C$. pulcherrima is related to the mannose to galactose ratio and, probably, intermolecular hydrogen bindings cause higher aggregation, which is directly related to the high adhesiveness in these RFP.

\section{CONCLUSION}

Restructured fish (Oligoplites palometa) products with galactomannan stored under freeze presented the lowest total volatile basic nitrogen (TVB-N) and thiobarbituric acid reactive substances (TBARS). The ability of galactomannan to interact with water contributed, in general, to low values of expressible water $\left(\mathrm{W}_{\mathrm{E}}\right)$, decreasing weight loss by cooking (WLC). This is important for the acceptance of products by making them soft and succulent. Despite the use of galactomannan resulted in inferior mechanical properties when compared to the use of transglutaminase, it maintained the integrity and shape of the restructured fish product over the storage time. The results show the viability of application of galactomannan from Caesalpinia pulcherrima as a binding agent for the development of restructured fish products stored under frozen conditions $\left(-18^{\circ} \mathrm{C}\right)$ for 120 days.

\section{ACKNOWLEDGEMENTS}

The authors thank the Embrapa Tropical Agroindustry, and the Meat and Fish Laboratory of the Department of Food Engineering of the Federal University of Ceará (UFC) by providing the facilities and support for this research.

\section{REFERENCES}

ANDRÉS-BELLO, A. et al. Effect of konjac glucomannan (KGM) and carboxymethylcellulose (CMC) on some physico-chemical and mechanical properties of restructured gilthead sea bream (Sparus aurata) Products. Food Bioprocess Technology, 6: 133-145, 2013.

ARAÚJO NETO, J. C. et al. Caracterização morfométrica, germinação e conservação de sementes de Caesalpinia pulcherrima (L.) SW. (Fabaceae: Caesalpinioidea). Ciências Agrárias Londrina, 35: 2287-2300, 2014.

BONFIM, R. C. et al. Aplicação de transglutaminase microbiana em produtos cárneos processados com teor reduzido de sódio. Ciência Rural, 45: 1133$1138,2015$.

BRASIL. Ministério da Agricultura, Pecuária e Abastecimento. Decreto $n^{\circ} 9.013$ de 29 de março de 2017. Diário Oficial [da] República Federativa do Brasil, Poder Executivo, Brasília, DF, 29 mar. 2017. Seção 3, p. 34. 
CARTONILHO, M. M.; JESUS, R. S. Qualidade de cortes congelados de tambaqui cultivado. Pesquisa Agropecuária Brasileira, 46: 344-350, 2011.

CERQUEIRA, M. A. et al. Structural and thermal characterization of galactomannans from nonconventional sources. Carbohydrate Polymers, 83: 179-185, 2011.

CONWAY, E. J.; BYRNE, A. An absorption apparatus for the micro-determination of certain volatile substances: the micro-determination of ammonia. Biochemical Journal, 7: 419-429, 1993.

COSTA, C. M. S. et al. Avaliação das propriedades nutricionais da carne das espécies Oligoplites palometa e Micropogonias furnieri de acordo com o número de lavagens. Revista Brasileira de Engenharia de Pesca, 8: 42-54, 2015.

KHOURYIEH, H. et al. Effects of xanthan-locust bean gum mixtures on the physicochemical properties and oxidative stability of whey protein stabilised oil-in-water emulsions. Food Chemistry, 167: 340-348, 2015.

KIM, T. K. et al. Effect of hydrocolloids on the quality of restructured hams with duck skin. Poultry Science, 97: 4442-4449, 2018.

KUNNATH, S. et al. Textural quality and oxidative stability of restructured pangasius mince: effect of protein substrates mediated by transglutaminase. Journal Food Science and Technology, 52: 351$358,2015$.

LIU, Y. et al. Principal component analysis of physical, color and sensory characteristics of chicken breasts deboned at two, four, six, and twenty-four hours postmortem. Poultry Science, 83: 101-108, 2004.

MAIA, M. O. et al. Natural thickener in raw and cooked fish-derived: microbiological, physicochemical, and sensorial acceptance. Científica, 43: 215-220, 2015.

MARTELO-VIDAL, M. J.; MESAS, J. M.; VÁZQUEZ, M. Low-salt restructured fish products from Atlantic mackerel (Scomber scombrus) with texture resembling turkey breast. Food Science and Technology International, 18: 251-259, 2012.

MEDEIROS, S. R. A. et al. Caesalpinia pulcherrima seed galactomannan on rheological properties of dairy desserts. Ciência Rural, 50:1-13, 2020.

MENDES, F. R. S. et al. Preparation and evaluation of hemicellulose films and their blends. Food
Hydrocolloids, 70: 181-190, 2017.

MONTEIRO, M. L. et al. Effect of transglutaminase on quality characteristics of a value-added product tilapia wastes. Journal Food Science and Technology, 52: 2598-2609, 2015.

MORENO, H. L.; BORDERÍAS, A. J.; BARON, C. Evaluation of some physico-chemical properties of restructured trout and hake mince during cold gelation and chilled storage. Food Chemistry, 120: 410-417, 2010

MORENO, H. L.; CARBALLO, J.; BORDERÍAS, A. J. Influence of alginate and microbial transglutaminase as binding ingredients on restructured fish muscle processed at low temperature. Journal of the Science of Food and Agriculture, 88: 1529-1536, 2008.

MORENO, H. L.; CARBALLO, J.; BORDERÍAS, A. J. Use of microbial transglutaminase and sodium alginate in the preparation of restructured fish models using cold gelation: Effect of frozen storage. Innovative Food Science and Emerging Technologies, 11: 394-400, 2010.

RAHARJO, S.; SOFOS, J. N.; SCHMIDT, G. R. Improved speed, specificity, and limit of determination of an aqueous acid extraction thiobarbituric acid method for measuring lipid peroxidation in beef. Journal of Agricultural and Food Chemistry, 40: 2182-2185, 1992.

RATHER, S. A. et al. Application of guar-xanthan gum mixture as a partial fat replacer in meat emulsions. Journal of Food Science and Technology, 53: 2876-2886, 2016.

SÁNCHEZ-ALONSO, I. et al. Testing caffeic acid as a natural antioxidant in functional fish-fibre restructured products. Food Science and Technology, 44: 1149-1155, 2011.

SOARES, K. M. P.; GONÇALVES, A. A. Qualidade e segurança do pescado. Revista do Instituto Adolfo Lutz, 71:1-10, 2012.

SOLO-DE-ZALDÍVAR, B. A. et al. Effect of freezing and frozen storage on restructured FISH prototypes made with glucomannan and FISH mince. Food Hydrocolloids, 41: 233-240, 2014.

SOTO-VALDEZ, H. et al. Effect of previous chilling storage on quality loss in frozen $\left(-20{ }^{\circ} \mathrm{C}\right)$ sierra (Scomberomorus sierra) muscle packed with a lowdensity polyethylene film containing butylated hydroxytoluene. Food Science and Technology, 35: 202-206, 2015. 
STATSOFT. Statistica for Window 7.0. Tulsa, OK

Statsoft, Inc. 2008.

THOMBRE, N. A.; GIDE, P. S. Rheological characterization of galactomannans extracted from seeds of Caesalpinia pulcherrima. Carbohydrate Polymers, 94: 547-554, 2013.

TRUONGHUYNH, H. T. et al. Freezing methods affect the characteristics of large yellow croaker (Pseudosciaena crocea): use of cryogenic freezing for long-term storage. Food Science and Technology, 18: 1-7, 2020.

YERLIKAYA, A. et al. The quality alterations of rainbow trout mince treated with transglutaminase. LWT - Food Science and Technology, 84: 815820, 2017. 